\title{
Research Article \\ Economics of production and marketing of wheat in Rupandehi district of Nepal
}

Meena Kharel*, Yuga Nath Ghimire, Krishna Prasad Timsina, Surya Prasad Adhikari, Sanjiv Subedi and Hema Kumari Poudel

\author{
National Agricultural Policy Research Centre, Khumaltar, Lalitpur, Nepal \\ *Correspondence: meenakhare177@gmail.com \\ *ORCID: https://orcid.org/0000-0002-2759-4967
}

Received: June 16, 2020; Revised: October 27, 2020;

Accepted: December 11, 2020; Available online: January 01, 2021

(C) Copyright: Kharel et al. (2021)

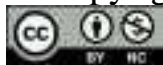

This work is licensed under a Creative Commons Attribution-NonCommercial 4.0 International License.

\begin{abstract}
Wheat is the third most important cereal crop of Nepal after rice and maize in terms of area. The study on profitability and marketing of wheat was conducted in the Rupandehi district in 2019. The household survey, focus group discussion, interview with the individual market actors such as input suppliers, producers, collectors, wholesalers, millers, and retailers in selected clusters was carried out. The study showed that the Benefit-Cost Ratio of wheat production (BCR) was 1.87. The marketing margins at three different levels of marketing farmwholesale, wholesale-retail, and farm-retail were also analyzed. The farm-retail marketing margin was found highest $(31.42 \%)$ and the farm-wholesale marketing margins were less $(15.78 \%)$. The producers' share in consumer price was $68.5 \%$ and the total gross margin was $56.36 \%$. This showed if value-added activities are absent in the chain, the shorter chain can provide a higher margin to farmers by bypassing the intermediaries.
\end{abstract}

Keywords: Benefit-cost ratio, Marketing margin, Producers' share

Correct citation: Kharel, M., Ghimire, Y.N., Timsina, K. P., Adhikari, S. P., Subedi, S., \& Poudel, H. K. (2021). Economics of production and marketing of wheat in Rupandehi district of Nepal. Journal of Agriculture and Natural Resources, 4(2), 238-245. DOI: https://doi.org/10.3126/janr.v4i2.33844

\section{INTRODUCTION}

Wheat (Triticum aestivum) is one of the third most important cereal crop after rice and maize in both area and production in Nepal and second in terms of human consumption. Currently, wheat is grown in $706,843 \mathrm{ha}$ with a total production of $1,949,001 \mathrm{mt}$ and the productivity is $2,757 \mathrm{~kg} / \mathrm{ha}$ (FAO, 2018). It occupies $20.916 \%$ of total cereal area and contributes $19.23 \%$ of the total cereal production in the country (MOALD, 2016/17). Similarly, productivity has steadily increased from 2.22 to 2.75 t/ha in the last ten years (FAO, 2018). The contribution of wheat in AGDP and GDP is $6.98 \%$ and $2.30 \%$ respectively (MoF, 2014). According to Pandey et al., 2017 wheat is mostly cultivated in terai region of Nepal constitute an area of $57.8 \%$ and production of $65.2 \%$. Wheat is considered a good source of protein, minerals, B-group of vitamins, and dietary fiber (Shewry, 2007; Kandel et al.,2018). The area as well production of wheat in Nepal has been distinctly increased after the introduction of semi-dwarf varieties from Mexico, which has contributed to the food supply (Pandey et al.,2019). However, the average productivity of wheat is low as compared to neighboring countries India and China, 3.37 ton/ha and 5.48 ton/ha respectively (Sendhil, et al., 2019). China, India,Russia, USA, France are the 
top five producers of wheat in the world (FAO, 2018). Wheat crop was considered as a minor cereal until early 1960s'. Now it is widely grown in all the three agro-climatic regions of the country ranging from 65 to 4000 masl. Nepal Agricultural Research Council has been recommended more than 40 improved varieties for different ecological regions of Nepal of which 17 for hill and 26 for terai region (Timsina et al., 2018). In terai region, more than $60 \%$ of wheat is produced among three regions of Nepal ( Subedi et al., 2020).

Although the production and productivity of wheat are increasing the domestic production is not enough to fulfill its demand and therefore a large amount is imported from neighboring countries. The export quantity and value were higher than import quantity and value during 1961 but after that import quantity and value were just seen less or with no export (Gairhe et al., 2017). Most of the farmers have been following less profitable, traditional production practices which result in a high cost of production, low productivity, and low profitability. The producer wheat prices, annual average flour retail price, per capita consumption are in rising trend (Gairhe et al., 2017). Similarly, the problem of marketing is mainly low price and the involvement of middlemen. Nepalese farmers typically depend heavily on middlemen in wheat marketing. A weak marketing system not only affects the farmers and the consumers but also the total economy. The poor marketing system in wheat has been felt as one of the major bottlenecks in accelerating the progress of the wheat sector. Generally, farmers are forced to sell at a very low price in season, which results in lower profit. According to Kalita (2017), due to high and fluctuating consumer prices, only a small share of the consumer rupee reaches the farmers. It is necessary to conduct empirical research to generate knowledge on the economics of agricultural production and its marketing. In this context, this study was carried out to analyze wheat profitability and marketing. Furthermore, this research analyses the benefit-cost ratio, marketing margin, and marketing channel of wheat in the study area.

\section{METHODOLOGY}

\section{Site selection}

Rupandehi district is located in the Lumbini province. It lies in terai in with an area of $1360 \mathrm{sq}$ $\mathrm{km}$ but some area extends up to the hill. The altitudinal range varies from $100 \mathrm{~m}$ to $1219 \mathrm{~m}$ above masl. The district headquarter is Bhairahawa which is the biggest market of Nepal bordering India. Total cultivable land in the Rupandehi district is 85122 ha which comes to be 60.2 percent of the total land area. The major cereal crops grown are rice, wheat, and maize. Wheat is the second most important crop after rice in the district. The productivity has been fluctuating in the district; it was cultivated in 29400 hectares and harvested 83,349 tonnes in 2017 which were 3,969 tonnes more compared to last season's harvest (MoALD,2017). According to Kathmandu post-2017, in the district, more than 40,000 people are involved in wheat farming. The most popular Nepali varieties among farmers in the district are Vijay, Aditya, Gautam, Bhrikuti, and NL-297. National Wheat Research Centre in Rupandehi district conduct research on 37 varieties of wheat. In the Rupandehi district, the major wheat production pockets in the district were identified through the consultation of the respective Agriculture Knowledge Centre (AKC). Large millers, wholesalers, and retailers were visited at different market places within and outside the selected pockets. The selected pockets were Siyari Municipality, Dhaddhagi; Rohihi Municipality, and Farsatighad Sudhodhan Municipality. 


\section{Data Collection}

Formats and checklists were prepared in advance to collect information from the market actors. From each pocket, samples were selected through simple random sampling, and the sample size was 100 households. One Focus Group Discussion (FGD) in each pocket was conducted. On average 15-20 farmers were present in each FGD. Individual market actors took part in the interview. The name of the collectors/local traders was identified from producers/sellers through the FGD. Similarly, the name of wholesalers and processers/millers were identified from the collectors/local traders. All these market actors were visited in their market destination and interviews were taken using the different checklists for each actor. Similarly, additional information was collected from secondary sources to validate the primary sources, and the information related to wheat production, marketing margin, producer share, supply, export, and import was also gathered.

\section{Gross margin}

The difference between the gross return and the variable cost incurred by any venture is gross margin. It is calculated by using the following formula.

Gross margin $=$ Gross return - Total variable cost

Where, Gross return $=$ Price $\times$ total quantity marketed

Total variable cost $=$ Summation of the cost incurred in all the variable items .

\section{Benefit-Cost Analysis}

For analyzing the cost of production, only the variable cost items were considered. The variable costs were farm expenditure on seed, fertilizers, irrigation, plant protection, labor, bullock, machine, etc. The total cost of production was calculated by adding all the expenditure on variable inputs. The benefit-cost analysis was analyzed by calculating the gross return and total variable cost from the wheat cultivation. The total variable cost of production was calculated by summing the variable cost items in the production process. For calculating gross return, income from the wheat sale was accounted. Timsina (2010), Adhikari (2011), Amgai et al. (2016), and Subedi et al. (2019) has also used a similar method to calculate the Benefit-Cost Ratio (BCR). The benefit-cost ratio was calculated using the following formula.

$\mathrm{B} / \mathrm{C}$ ratio $=$ Gross return $/$ Total variable cost

\section{Marketing margin and production share}

Marketing margins from the data set was estimated as different stages of marketing and producer share in consumer rupee. The simple arithmetic mean technique was used to compare the prices at different levels of market operation. The marketing margins of farm-wholesale, wholesale-retail, and farm-retail were calculated by using the following equations (Hassan et al., 2017). Hassan et al. (2017) has also used a similar formula to calculate the marketing margins of farm-wholesale, wholesale-retail, farm-retail production share in consumer price.

Farm-Whole sale marketing margins $=\mathrm{WP}-\mathrm{FP} / \mathrm{WP} * 100 \ldots \ldots \ldots$ (eq. 1$)$

Whole sale-retail marketing margins $=\mathrm{RP}-\mathrm{WP} / \mathrm{RP} * 100 \ldots \ldots \ldots \ldots$ (eq. 2 )

Farm-Retail marketing margins $=\mathrm{RP}-\mathrm{FP} / \mathrm{RP} * 100 \ldots \ldots \ldots \ldots$ (eq. 3)

In these equations, FP is the average farm Price, WP is the mean wholesale price and RP is the average retail price.

Producers' share in consumer price $=\mathrm{FP} / \mathrm{RP} * 100 \ldots \ldots \ldots \ldots$ (eq. 4$)$ 


\section{RESULTS AND DISCUSSION}

\section{Cost of production}

The total variable cost in the study area was found to be Rs.47571.46 per hectare(ha).In the study area, cost of human labor (22.95\%), seed cost $(20.50 \%)$, land preparation $(17.57 \%)$, chemical fertilizer $(16.97 \%)$, harvesting $(16.50 \%)$, and irrigation $(5.48 \%)$ was found to be the major cost attributing items among all variables. During land preparation the farmers use a tractor. Human labor is mostly used in seed sowing, chemical fertilizer application, harvesting, load-unload, and packaging. Similar to Bist et al. (2017) the human labor was found highest cost attributing factor followed by the cost of seed. Mostly tractor is used in land preparation, the combination of both manual and combine harvester were used for harvesting. The cost of irrigation was less because in the study sites there was a facility of canals. Bhujel et al. (2009) reported in both traditional and resource conservation tillage (RCT) methods, fertilizer cost was found major contributor, $24 \%$ and $29 \%$ of the total cost respectively. Similarly, Ghimire et al.(2013) found chemical fertilizer (23\%) as the major cost item for wheat production. The details of the variable cost of wheat production are shown in Table 1.

\section{Table 1: Average cost of wheat production per hectare}

\begin{tabular}{ll}
\hline Cost attributing items & Variable cost in the study area(NRS) \\
\hline Land Preparation & 8362.9 \\
Cost of Seed & 9753.06 \\
Chemical fertilizer & 8076.1 \\
Irrigation & 2610 \\
Harvesting & 7850 \\
Total Human Labour & 10919.4 \\
Total Production cost & 47571.46 \\
\hline
\end{tabular}

Source: Field Survey, 2019

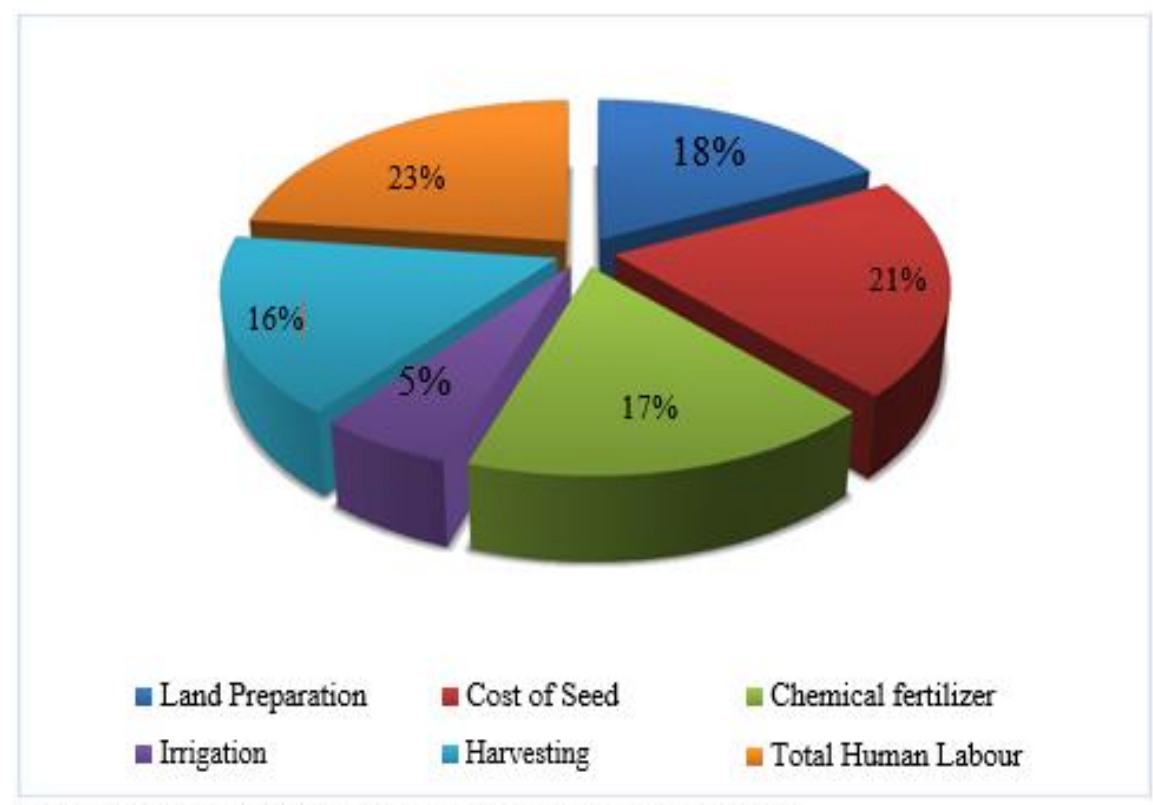

Fig:1 Share of different cost in wheat production

\section{Gross Margin}

The average total returns from wheat production in one hectare of land in the study area were calculated NRs. 41473.3. 
Gross Margin $=$ Gross return (ha)- Total variable cost (ha)

NRs (89044.8-47571.46)= NRs 41473.3per ha

\section{Benefit-Cost Analysis}

The benefit-cost analysis was calculated by computing the variable cost of production which includes land preparation, cost of irrigation, cost of seeds, human labor cost, fertilizer cost, harvesting cost. Table 1 showed that the variable cost of production of the wheat crop was NRs. 47571.46 per ha. Similarly, per ha benefit /gross return was NRs.89044.8 and gross margin was NRs. 41473.3 per ha. The benefit-cost ratio (BCR) was estimated by dividing the gross return by costs. The BCR was 1.87 . The BCR in the study area was found to be greater than one. This result shows that wheat production is financially feasible in terai region. The benefit-cost ratio can also be expressed as return per rupee invested. Thus if we invest one rupee we can get a return of Rs 1.87. Bista et al.(2017), found a benefit-cost ratio of 1.79 in wheat production in the Kanchanpur district. Bhujel et al.(2009) reported a benefit-cost ratio of 1.77 in a traditional method and 2.19 in machine used RCT in wheat production in the eastern terai region of Nepal. Ghimire (2013) and Dhital (2017) found BCR of 1.38 and 1.22 respectively in wheat production in Nepal. Similarly, Gairhe et al. (2017) also reported BCR in wheat production under irrigated and rainfed conditions as 1.2 and 1.3 respectively.

\section{Marketing margin and production share}

Marketing margins at different stages of marketing and producer share in consumer rupee have been estimated from the data set. The simple arithmetic mean technique was used to compare the prices at different levels of market operation. The marketing margins at three different levels of marketing: farm-wholesale, wholesale-retail, and farm-retail were calculated by using the equations 1 to 3 . The farm-retail marketing margin was found to be the highest $(31.42 \%)$ while the farm-wholesale marketing margin was the lowest $(15.78 \%)$. The producers' share in consumer price was $68.5 \%$ and the total gross margin was $56.36 \%$ as shown in table 2 . It has been reported that the farmers who sold their produce directly to consumers received a higher share of the consumer's price than did those who sold their products through agents (Vasishet al., 1995).

\section{Table 2: Marketing margin and production share}

\begin{tabular}{cll}
\hline SN & Particulars & Percentage \\
\hline 1 & Farm-Wholesale marketing margins & 15.78 \\
2 & Wholesale-retail marketing margins & 22.80 \\
3 & Farm-Retail marketing margins & 31.42 \\
4 & Farm-processer marketing margins & 25 \\
5 & Producers' share in the consumer price & 68.5 \\
6 & Total Gross Margin & 56.36 \\
\hline
\end{tabular}

\section{Marketing channel}

Aharya and Agrawal (1999) defined agricultural marketing as comprising of all activities involved in the supply of farm input to the farmers and the movement of agricultural products from the farmers to the consumers. In the study site, many actors in the wheat value chain play different roles in product marketing from input supply to production, collection, processing/ milling, wholesaling, retailing, and ultimately to consumers. The major input suppliers in the wheat value chain are agro-vets, seed producer cooperatives, NARC, AKC, agriculture machinery dealers, fertilizers dealers, and financial institutions. They supply inputs and also provided technical advice to farmers. 
Farmers get inputs required for the wheat production from local level input suppliers mostly agro-vets. Small collectors are permanent residents of their collection areas. The collected wheat is then sold to the large traders in the district. In some clusters, they took to the large millers. Large millers are then sold to wholesalers and retailers inside the district and also outside the district like Kathmandu, Pokhara, Hetauda, in the hill district, and other districts. The marketing channel producer-collector-millers-retailers-consumers was found as a major marketing channel. In the case of other staple food crops such as rice, Sapkota et al. (2018) identified producer-collector- millers-consumer as the major marketing channel of rice marketing in the Naghlebhare rice block of Kathmandu district of Nepal. Major market channel for wheat in the study area have been identified as:

\section{First Channel \\ Producer $\longrightarrow$ Consumer}

\section{Second Channel}

Producer $\longrightarrow$ local trader $\longrightarrow$ Wholesaler $\longrightarrow$ Consumer

Third Channel

Producer $\longrightarrow$ local trader $\longrightarrow$ Wholesalers $\rightarrow$ Small Millers $\rightarrow$ Consumer

Fouth Channel

Producer $\longrightarrow$ local trader $\longrightarrow$ Large Millers $\longrightarrow$ Retailer $\longrightarrow$ Consumer

Fifth Channel

Producer $\longrightarrow$ local trader $\longrightarrow$ Wholesaler $\rightarrow$ Large Millers $\rightarrow$ Retailer $\longrightarrow$ Consumer

Figure 2. Major market channel for wheat in the study area

Source: Field Survey, 2019

\section{Constraint on production and marketing of wheat}

In the study area, the farmers were facing several production constraints that slowed down the speed to get the potential yield of wheat crop. Timely unavailability of improved seeds and fertilizers, limited technical knowledge of farmers, disease, and pest incidence were the major constraints on wheat production. The constraints faced by farmers while marketing wheat grain in the study area were fluctuating market price, lack of storage facility, limited market information, and limited infrastructures and services available for quality assurance.

\section{CONCLUSION}

The average cost of wheat production was calculated NRs 47571.46, gross return NRs. 89044.8 and gross margin of NRs 41473.3 per hectare. The BCR (1.87) greater than one indicated the financial viability of wheat production. Among the variable cost items, the cost of human labor $(22.97 \%)$ was the major cost item followed by seed cost $(20.50 \%)$, land preparation $(17.57 \%)$, chemical fertilizer $(16.97 \%)$, and harvesting $(16.50 \%)$. The efficient use of seed and fertilizer can reduce the production cost. The use of machinery could be helpful to reduce the human labor cost. The farm-retail marketing margin was found to be the highest (31.42\%) while the farm-wholesale marketing margin was the lowest (15.78\%); it is due to the involvement of the middleman which results in to increase in the final price. The supply chain in the study area was found to be dominated by numerous intermediaries who did not add significant value along the chain but their involvement affects the final price. The situation is further stressed by a very 
little bargaining power of the farmers along with the problem of timely unavailability of the quality fertilizers and seed. The producers' share in consumer price was $68.5 \%$ and the total gross margin was $56.36 \%$. This showed if value-added activities are absent, the shorter chain can provide higher margin to farmers by bypassing the intermediaries.

\section{ACKNOWLEDGEMENTS}

Authors want to thank Nepal Agricultural Research Council (NARC) for providing fund to conduct this research. Authors extend sincere gratitude to respondent farmers of Rupandehi district who provided valuable information to complete this study. All officials of NWRP and others who directly/indirectly helped are highly acknowledged.

\section{Authors' contribution}

M. Kharel was the lead investigator, collected data, and wrote the manuscript. S.P. Adhikari, S. Subedi, and H.K. Poudel were responsible for collecting data and revision of the paper. Y.N. Ghimire and K.P. Timsina provided the comments and feedback for the finalization of the paper. The final form of the manuscript was read and approved by all authors.

\section{Conflicts of Interest}

The authors declare no conflicts of interest regarding the publication of this manuscript.

\section{REFERENCES}

Acharya, S. S., \& Agarwal, N. L. (1999). Agricultural Marketing in India, 3rd Ed. Oxfordand IBH Publishing Co. Pvt.Ltd, New Delhi, India. 402 p.

Adhikari, R. (2011). Economics of Organic Rice Production. Journal of Agriculture and Environment, 12, 97-103. https://doi.org/10.3126/aej.v12i0.7569

Amgai, S., Adhikari, B.K., \& Kadariya, M.(2016). Economic analysis of cost of production of apple in Mustang district of Nepal. The Journal of Agriculture and Environment, 17, 141-147,

Bhujel, R. B., Jha, R. N., \& Yadav, B. (2009). An Empirical Analysis of Resource Productivity of Wheat in Eastern Tarai Region of Nepal Regional Agriculture Research Station, Tarahara, Sunsari, Nepal. Nepal Agricultural Research Jounal, 9, 99108

Bist, V., Acharya, N., Adhikari, S., \& Dhungana, S. (2017). Resource productivity analysis of wheat production in Kanchanpur district, Nepal. Journal of Pharmacognosy and Phytochemistry, 6(1), 210-212.

Dhital, B. (2017). Economy of Production and Labor Requirement in Major Field Crops of Kavre,Nepal.International Journal of Environment, Agriculture and Biotechno logy, 2(1), 350-353.

FAO.(2018). FAOSTAT. faostat@fao.org

Gairhe, S., Karki, T.B., Upadhyay, N., \& Sapkota, S.(2017).Trend analysis of wheat area, production and productivity in Nepal: An Overview, Proceedings of 30th National Winter Crops Workshop.

Ghimire, S., Dhungana, S.M., Krishna, V., Teufel, N., \& Sherchan, D.P. (2013). Biophysical and Socioeconomic characterization of cereal production system of central Nepal. CIMMYT Working paper 9.

Hassan, $\quad$ S., Qasim, M., Mahmood, I., Bashir, A., \& Ahmad, N.(2017).An Economic Estimation of Wheat Marketing Margins: A Context of Pakistan. J. Appl. Environ. Biol. Sci., 7(3), 150-156 
Kalita, B.(2017). Marketing Efficiency, Price Spread, Share of Farmers International Journal of Advance Research and Development In Case Of Horticultural Markets of Assam, 2, 65-72

Kandel, M., Bastola, A., Sapkota, P., Chaudhary, O., Dhakal, P., \& Shrestha, J. (2018). Analysis of genetic diversity among the different wheat (Triticumaestivum L.) genotypes. Turkish Journal of Agricultural and Natural Sciences, 5(2), 180185.

Kathmandu Post. (2017). Rupandehi sees surge in wheat production. Retrived from: https://kathmandupost.com/money/2017/04/27/rupandehi -sees-surge-inwheat-production.

MOALD. (2017). Statistical information on Nepalese agriculture 2073/74 (2016/17). Agribusiness promotion and statistics division, Ministry of Agriculture and Livestock Development, Kathmandu, Nepal.

MoF. (2014). Economic Survey. Ministry of Finance, Singh Durbar, Kathmandu, Nepal. Pandey, D., Chaudhari, H.K., Upadhyay, S.R., Gautam, N.R., Ghimire, B.R., Shrestha, J., \& Thapa, D.B. (2019). Participatory on-farm evaluation of wheat varieties. Journal of Agriculture and Natural Resources, 2(1), 312-321.

Pandey, G, Yadav, L., Tiwari, A., Khatri, H., Basnet, S., Bhattarai, K., Gyawali, B., Rawal, N., \& Khatri, N.(2017). Analysis of Yield Attributing Characters of Different Genotypes of Wheat in Rupandehi, Nepal. International Journal of Environment, Agriculture and Biotechnology, 2(5), 2374-2379

Sapkota, B.K., Dutta, J.P., Chaulagain, T.R., \& Subedi, S. (2018) Production and marketing of rice in Naghlebhare rice block, Kathamndu: an economic analysis. Nepalese Journal of Agricultural Sciences, 16, 145-155

Sendhil, R., Kiran, T.M., K., \& Singh, G. P. (2019). Wheat Production in India: Trends and Prospects [Online First], Intech Open, DOI: 10.5772/intechopen. 86341.

Shewry, P.R. (2007). Improving the protein content and composition of cereal grain. Journal of Cereal Science, 46(3), 239-250.

Subedi, S., Ghimire, Y.N., Gautam, S., Poudel, H.K., \& Shrestha, J. (2019). Economics of potato (Solanum tuberosum L.) production in terai region of Nepal. Archives of Agriculture and Environmental Science, 4(1), 57-62, https://dx.doi.org/10.26832/24566632.2019.040109

Subedi, S., Ghimire, Y. N., Devkota, D.,Kharel, M.,Gautam, S., Sharma, B., \& Sapkota, B. K. (2020). Socio-economics of wheat production in Kailaliand Sunsari districts of Nepal. Journal of Agriculture and Natural Resources, 3(1), 29-37.

Timsina, K.P. (2010). Economics of Ginger Production: A case study of Makawanpur district, Nepal. Journal of the Institute of Agriculture and Animal Sciences, (31\&32), 35-41.

Timsina, K.P., Ghimire, Y.N., Gauchan, D., Subedi S., \& Adhikari, S.P. (2018). Lessons for Promotion of New Agricultural Technology: A Case of Vijay Wheat

Variety in Nepal. Agriculture and Food Security, 7, 63. https://doi.org/10.1186/s40066-018-0215-z

Vasisht, A. K., Singh C., \& Singh, I. (1995) Temporal and Spatial Change in the Price spread of Agricultural Commodities in India. Indian Journal of Agriculture Marketing, Conference Special, 9(1), 1-11. 